\title{
The Wheels of A Command Economy: Allocating Soviet Vehicles
}

\author{
Valery Lazarev \\ University of Houston, Department of Economics, and the Hoover Institution \\ E-mail: vlazarev@uh.edu
}

Paul R. Gregory

University of Houston, Department of Economics

E-mail: pgregory@uh.edu

October 2001

This research was funded by grants from the Hoover Institution and from the National Science Foundation. 


\begin{abstract}
This paper traces the formal and informal allocation of vehicles by the Soviet administrative-command economy in the early and mid 1930s using the very same documents as did the Soviet dictator some 70 years earlier. Vehicles should present Soviet resource allocation in its most favorable light, since their production and allocation was highly centralized and tightly monitored. This case study, however, shows the complicated reality of vehicle allocation. Most newly-produced vehicles were initially allocated to large wholesale users directly by the top party leadership through quarterly plans, amid gaming tactics employed by the major players. Consumers distorted information; planners fought against arbitrary, unjustified requests; firm rules were lacking. This centralized "planned" distribution was anything but orderly as ad hoc political decrees overturned quarterly plans, especially during supply shocks; wholesalers ignored planned instructions by keeping vehicles for themselves or redirecting them to others; and the producer influenced allocation through its control of the planning "aftermarket". Existing stocks of vehicles were redistributed by administrative mobilizations that were resisted and thwarted by those losing vehicles. Behind the scenes of planning, a complicated informal market reallocated used vehicles.
\end{abstract}




\section{INTRODUCTION}

The Soviet command economy, which emerged in late 1920s as Stalin's team took control and existed in basically unchanged form until its breakdown in 1991, represents an extreme case of governmental control of the economy. It was characterized by the administrative planning of production and distribution, state ownership of the means of production, and the control of economic decision making by a dictatorship. The Soviet command system spread to Eastern Europe, China, and Cuba. How it worked, therefore, may yield instructive lessons for economies that combine some of its features, such as political dictatorship, state ownership, and/or administrative planning. The Soviet system created, at its peak, the world's second largest military power and produced relatively high rates of growth from the late 1920s to the mid 1960s, but these achievements were accompanied by excess mortality, declining real consumption, industrial development heavily skewed toward military production, and the use of penal labor, costs the dictator accepted to secure the regime against internal and external threats. These apparent sacrifices of economic rationality have been widely discussed in the literature. ${ }^{1}$

This paper contrasts the theory and reality of the Soviet administrative-command system by using the recently-opened records of the Soviet state and party archives. In theory, all capital and natural resources were claimed (owned) by the state in order to ensure the economy caters to the interests of the dictator. In theory, a central planning apparatus, for the first time in economic history, replaced the market to command the allocation of major commodities. In

\footnotetext{
${ }^{1}$ Gregory and Stuart, Russian and Soviet Economic Structure and Performance; Hunter and Szyrmer, Faulty Foundations: Soviet Economic Policies 1928-1940, and others.
} 
theory, the dictator exerted control of the resource allocation process by issuing orders to subordinates which were universally obeyed. This "scientific planning" stereotype pictured a highly centralized allocation process in which planners, following the party's instructions, planned outputs and used "scientific" norms to construct a consistent distribution plan for key industrial commodities from input requests of non-opportunistic ministries and regional administrations, who distributed them according to economic criteria among their subordinate organizations. $^{2}$

The Western literature has attempted to examine the validity of these stereotypes: Scholars have pointed out that Soviet "scientific" planning was "non-scientific". Plans were rarely realized and frequently amended. ${ }^{3}$ Enterprise managers evaded plans and overdemanded resources. ${ }^{4}$ Rather than being an economy of "balances", the Soviet economy was a "shortage economy" due to over-optimistic ("taut") target-setting, ${ }^{5}$ the state's inability to impose hard budget constraints on its enterprises, ${ }^{6}$ planning errors, ${ }^{7}$ and perhaps even deliberate creation of opportunities for corruption. ${ }^{8}$ An exhaustive empirical study by Zaleski showed that the rate of

\footnotetext{
${ }^{2}$ Gosplan SSSR, Metodicheskie ukazanii $k$ rasrabotke gosudarstvennykh planov ekonomicheskogo I sotsial'nogo razvitiia SSSR.

${ }^{3}$ Jasny, Soviet Industrialization, 1928-1942; Zaleski, Stalinist Planning for Economic Growth 19331952; Wilhelm, "The Soviet Union Has an Administered Not a Planned Economy."

${ }^{4}$ Berliner, Factory and Manager in the USSR; Granick, Management of Industrial Firms in the USSR.

${ }^{5}$ Hunter, "Optimal Tautness in Development Planning."

${ }^{6}$ Kornai, Economics of Shortage.

${ }^{7}$ Kushnirsky, Soviet Economic Planning, 1965-80.

${ }^{8}$ Shleifer and Vishny, "Pervasive Shortages under Socialism."
} 
plan compliance was so low that the term "planned economy" is a misnomer. ${ }^{9}$ Instead impulsive "resource management," largely outside the realm of formal planning, was the principal instrument of resource allocation. Powell, in an under-recognized article, proposed the only "model" of soviet resource management, suggesting that the system "worked" through nonmarket signals from subordinates to their superiors. ${ }^{10}$ Powell's model was based on a thought experiment, given that he had no materials on how the system actually worked.

\section{Unresolved Issues}

This paper examines the following unresolved issues concerning the Soviet planned economy: First, although Western studies of the Soviet enterprise destroyed the myth of microeconomic obedience to orders from above, ${ }^{11}$ the myth of obedience, or non-opportunistic behavior, by high level officials has persisted. The dictator gave orders to planners and to ministerial officials, who did their best to carry out these orders. Scholars have not been able to examine this "centralization myth" because of the excessive secrecy surrounding the Soviet system. We do not know who was obedient to the wishes of the dictator - who behaved opportunistically and who was loyal. ${ }^{12}$

Second, although the myth of the complete replacement of the market by the plan has been destroyed by the discovery of a large underground retail economy, the presence of market

\footnotetext{
${ }^{9}$ Zaleski, Stalinist Planning for Economic Growth 1933-1952.

${ }^{10}$ Powell, "Plan Execution and the Workability of Soviet Planning."

${ }^{11}$ Berliner, Factory and Manager in the USSR; Granick, Management of Industrial Firms in the USSR.

${ }^{12}$ Belova and Gregory, "Dictator, loyal, and opportunistic agents: The Soviet archives on creating the soviet economic system.”
} 
or quasi-market forces at relatively high levels remains to be studied. ${ }^{13}$ Hayek and Mises questioned the feasibility of a single decision maker replacing the market already in the 1920s and 1930s. ${ }^{14}$ What we do not know is the extent to which high-level planning, ministerial, and territorial officials used market-like allocations in wholesale and capital markets.

Third, the planning stereotype says virtually nothing about how the Soviet system redistributed existing stocks of assets. Economies must have ways of redistributing capital assets from lower to higher uses to adjust for changing conditions; so we must assume that the Soviet economy had some practical procedure in place.

Fourth and most generally, we lack a picture of how and how well resource management was carried out and its relationship to planning. Why did adjustments and interventions take place after the plan was completed? Were they themselves chaotic or welfare improving?

The excessive secrecy surrounding the Soviet system prevented Western researchers from dealing with these four issues. Gregory showed that we knew little about the practical operation of the Soviet economy above the level of the enterprise - about how planning (or Zaleski's resource management) actually functioned. ${ }^{15}$ The opening of the formerly-secret State and Party Archives provides, at long last, an inside view of actual Soviet resource allocation. ${ }^{16}$ We can

\footnotetext{
${ }^{13}$ Grossman, "The Second Economy of the USSR"; Treml, "Production and Consumption of Alcoholic Beverages in the USSR: A Statistical Study."

${ }^{14}$ Hayek, "Socialist Calculation: The Competitive Solution"; Mises, Socialism: An Economic and Sociological Analysis.

${ }^{15}$ Gregory, Restructuring the Soviet Economic Bureaucracy.

${ }^{16}$ Our study uses the archives of the Council of Ministers (State Archive of the Russian Federation Gosudarstvenny arkhiv Rosiyskoy Federatsii, hereafter referred to as GARF - Fond 5446), minutes of the
} 
now use the same documents that the dictator, the planner, and the industrial minister themselves used to make their decisions and operate their organizations.

We could tackle the four enumerated issues either generally or through case studies. Given the enormous complexity of the Soviet economy, we conclude that the case-study approach provides the best starting point. This paper traces the allocation of a single capital asset - vehicles, one of the most "deficit" of commodities - in the 1930s, using the operational plans and routine documentation, which have fallen below the radar screen of past studies based on published plans. We exclude production of vehicles from our study. Shocks to production are exogenous in our analysis.

Vehicle distribution should present Soviet resource allocation in its most favorable light with respect to the Mises-Hayek information problem critique: In this period, a maximum of 160,000 vehicles were distributed per year; production was highly concentrated and fairly homogeneous; it should have been easy to keep track of stocks of cars and trucks; and their allocation was directed by a three-person committee of the top political/economic leadership. The Soviet State and Party Archives provide researchers with a unique opportunity to place themselves in the shoes of the Soviet dictator. We can reconstruct the allocation of vehicles

Politburo (RGASPI, formerly Central Party Archives, Fond 17, Op.3), archives of Gosplan (State Archive of the Economy - Gosudarstvenny arkhiv ekonomiki, hereafter referred to as RGAE - Fond 4372), the Ministry of Heavy Industry (RGAE, Fond 7622), the Central Statistical Bureau (RGAE, Fond 1562), the Central Party Control Commission (RGANI, Formerly Archive of the Central Committee of the CPSU, Fond 6), GULAG (GARF, Fond 9414). The latter two are available in the Hoover Institution archives. For general descriptions of these archives see: State Archival Service, Stalinskoe Politburo, Kratki putevoditel. 
using the very same documents (including penciled margin comments), petitions, and investigative reports as the dictator's own allocators.

A vehicle is a long-lived asset that provide services over a period of years. The services of vehicles can be allocated by distributing new production and/or redistributing existing stocks from one economic agent to another. Given that new production was large relative to the existing stock and the depreciation rate was high in the Soviet Union of 1930s, the allocation of new production had more of an effect than redistribution. Nevertheless, we focus on two basic allocation problems: First, given production and imports, how were vehicles allocated among the virtually unlimited number of potential claimants? Second, given the current allocation of existing stock, how were vehicles reallocated from one user to another. Thus, we examine the institutions that the Soviet dictatorship put in place to direct the initial and secondary allocations of capital assets. If the distribution system consisted of one omniscient planner, then these answers would reduce to solving a simple algebra problem. This case study shows that the institutional framework and procedures of vehicle allocation were far more complicated. A number of players participated in the game: the dictator, the dictator's loyal agents, wholesale/intermediate organizations, the producer, and the final users. Each played the game differently.

\section{Preview of Findings}

Our case study uncovers a number of unexpected findings for those schooled on the existing literature: First, we find that planners, the agents most stressed in the literature, were limited to the relatively-unimportant technical role of intermediary between consumers, expressing their demands in requests, and the dictator who had the ultimate decision-making

power. Second, we find that, although formally most vehicles were allocated by centralized quarterly plans, the dictator did not commit to the plans it approved, especially during periods 
of shocks. Regular planning was disrupted and often overridden by ad hoc decrees. The dictator's appropriation of unlimited discretionary power was the ultimate source of Zaleski's "resource management." Third, the producer also could influence the primary allocation at the margin in a previously-unobserved planning "aftermarket," although the dictator should have been able easily to monitor and control the producer. Fourth, the system of planning/resource management was supplemented by redistributions of control rights of existing stocks, or "mobilizations", which were frequently disobeyed or ordered at lower levels. Fifth, although some "retail" markets were permitted, the extent of illegal or semi-legal secondary markets was incomparably larger, because multitudes of consumers were denied access to official channels of distribution. Disfranchised consumers even resorted to home assembly from spare parts or decommissioned vehicles - practices that were especially annoying to the dictator, who sought absolute control over such valuable assets. Most generally, we find that, although the dictator claimed all output and existing stock of vehicles, it lacked the capacity to monitor distribution to enforce its claims. Monitoring capacity was low because the dictator, unwilling to share decision-making power, paradoxically had to rely on opportunistic industrial and regional leaders. The actual distribution system constituted a complicated "machine" where each wheel, bolt and nut was self-interested and used its political power and/or information advantages to secure undivided control over available resources.

\section{OFFICIAL WHOLESALE DISTRIBUTION OF NEW PRODUCTION}

Soviet industry began its own mass vehicle manufacturing program in the early 1930 s to end reliance on imports. Less than 10,000 vehicles were distributed per quarter in 1932, when a new factory in Nizhny Novgorod (Gorky) started to produce Ford models 'A' (car) and 'AA' 
(1.5-ton truck). ${ }^{17}$ By the mid 1930s, production increased to approximately 40,000 per quarter. The Soviet State and Party Archives provide a few quarterly distribution plans along with voluminous files of requests for vehicles and related correspondence. Investigations of abuse and malfeasance provide the most valuable information on the informal workings of quasimarket institutions. The annual and five-year vehicle plans were found to have little operational significance and are not analyzed here. ${ }^{18}$

The following players participated in the official distribution process:

Dictator refers to the supreme leadership of the Soviet Union: the highest party body, Politburo, and the government proper, the Council of Peoples' Commissariats, Sovnarkom, that formed together an interlocking directorate. The Politburo was comprised of ten to twelve leading party officials, with Stalin as the General Secretary. The Politburo, in its formal or informal meetings, set priorities, which could be either general, such as the number of cars to be produced in the first quarter, or very specific, such as allotting two cars for a military research facility. ${ }^{19}$ The Politburo did not usually delve into the details of plan preparation, ceding this

\footnotetext{
${ }^{17}$ Few more models of trucks were produced in two older factories, in Moscow and Yaroslavl.
}

${ }^{18}$ Among all the archival materials on the Second five-year plan (1933-1937), there is only one very rough vehicle distribution plan by end users, which shows beginning stocks and proposed ending stocks, the latter being based not upon summaries of orders but upon general perspectives. This plan had no operational significance: produced only in 1934, it was never mentioned in later planning documents. For some years of the period (but not for all) annual plans were developed but quarterly plans seldom refer to them as well.

19 A typical Politburo priority statement would read: "[Planning bodies] are advised to take into consideration for freight transport and the transport of materials to construction sites, the authorization of 1500 trucks for 1933. It is proposed to secure in the first order the needs of the following areas: [provides 
authority to the government. Formally, the government, Sovnarkhom, was in charge of quarterly plans, although pre-approval by the Politburo might precede. The Politburo also made numerous ad hoc interventions (to be discussed below), yet the bulk of routine vehicle distribution went through government, rather than party, channels. ${ }^{20}$ Within Sovnarkom, an unofficial special commission comprised of its head, Molotov (the prime minister), and two deputies, all members of the Politburo, made the actual allocation decisions for vehicles. This commission rendered its decisions, often with consumer representatives present to lobby their requests. ${ }^{21}$ The Molotov committee did not meet regularly and made its decisions often in flurries of activity. ${ }^{22}$ The head of the Transportation Department of Sovnarkom, an official by the name of Gorbachev (probably unrelated to the later General Secretary), handled all the

list of territories]. [Planners are] obliged to foresee in the quarterly plans allocation... of no less than 75\% [of these 1500 trucks] in the first half year." (RGASPI.17.3.914.35-36).

${ }^{20}$ There is only one recorded instance of Comrade Stalin's personal exercise in vehicle distribution planning. This happened in the autumn of 1933 when the issue of providing agriculture with the means of transportation was of particular importance. (RGASPI.81.3.100.25-33.) We are grateful to R.W. Davies for sharing these documents with us.

${ }^{21}$ Meetings were open to major consumers but no strict rules for participation existed. Complained Chernov, the head of one governmental body: "In Gosplan's project for the second quarter, we were allotted 20 trucks - they were struck in the commission. I could not represent our interests, because I did not know about the meeting of the commission." (GARF.5446.14.20295.25)

${ }^{22}$ Normally, there were no more than two decisions per day made either personally by a commission member or by "polling." In rare cases, a large number of decisions fell on the same day, typically on the days of formal meetings or immediately following them. On January 21, 1933, 26 decisions were signed totaling two-thirds of all decisions made in that month. 
paperwork for vehicles; all draft government documents bear only his signature. All vehicle decisions were issued as secret decrees, signifying their importance. The Molotov Commission was also a direct distributor of vehicles from its own reserve fund; it could also order the redistribution of vehicles from the "funds" (allocation quotas) of other organizations.

Planner - The State Planning Commission (Gosplan) - was a functional committee of Sovnarkhom and played a role in matching supply and demand, but had very little decisionmaking authority. Departments of Gosplan served as planners for particular commodities, but the importance of vehicles led to an unusual planning structure: The "Auto and Aero" Department of Gosplan collaborated with a specialized planning body, Central Administration of Road Transport (hereafter, CART), which collected, organized, and processed orders from different channels for Gosplan. ${ }^{23}$ Unlike production plans, which were handed down from above, the Planner had few instructions to guide its allocations of vehicles. Vehicles were an investment good, but the investment plan was stated in monetary terms and was not broken down by types of goods. Faced with arbitrary requests, the Planner (Gosplan) routinely insisted that vehicle consumers "defend" their requests by demonstrating they conformed to state objectives and pushed for input norms:

\footnotetext{
${ }^{23} \mathrm{We}$ assign this organization that we give here an unconventional, yet accurate, acronym CART. Its official name, structure, and affiliation changed every two or three years. In the period 1931 to 1935 , CART (most often referred to in the documents as Tsudortans) was the prime collector of vehicle orders, as well as the only road construction company and also an umbrella for a number of regional public transportation companies. CART of trucks. In mid-1933 CART temporarily supplanted Gosplan on automobile issues under a general program to relieve Gosplan of detailed allocation planning. The job of preparing draft distribution plans was returned to Gosplan shortly thereafter.
} 
"Gosplan and CART have carried out considerable work on checking orders from organizations ordering vehicles, during which, we uncovered an extreme lack of justification of orders. Thus the Ministry of Supply came with an order for 9,500, the Ministry of Heavy Industry with 40,000 and then with 16,000, the Ministry of Agriculture with 22,000 and then 16,000 , and so on, without any connection to the capital investment plan, or analysis of freight transport by organization or region. A detailed analysis of the situation with respect to the organization and exploitation of auto stocks points to the necessity of surveys of the largest vehicle users... Gosplan thinks it essential to require each organization and each republic to strictly plan the use of all vehicle allotments with the goal of fulfilling state decrees concerning auto transport, liquidating their sloppy and unjustified requests...,24

Initially faced with tremendous excess demand, Gosplan insisted that wholesale consumers reduce the demands of their subordinates. By the end of the 1930s, vehicle consumers increasingly used norms to prepare their vehicle requests, but, as late as 1940, there were still no standardized norms and few substantive calculations were made. ${ }^{25}$

Supplier consisted of the main administration for tractor and automobile industry and the automobile supply trust, both of the Ministry of Heavy Industry. Production and sales were thus formally separated, although both "halves" cooperated closely. The Supplier prepared monthly delivery plans, which adjusted quarterly distribution plans to actual production, and issued the all-important authorizations to buy vehicles. On at least two occasions in the 1930s, the Supplier was authorized to prepare its own independent vehicle distribution plans but this was

\footnotetext{
${ }^{24}$ GARF 5446.14a.628.143-4. Note that 40,000 vehicles were planned to be produced for that quarter, meaning that initially the Ministry of Heavy Industry claimed all vehicles for itself!

${ }^{25}$ Such input-norm calculations were based on simple technological coefficients and did not take costs into consideration. A typical petition would essentially read: "We need to move X tons of gravel per day; one truck can transport Y; hence we need X/Y trucks.”
} 
not a common practice. The Supplier played an important role in the planning aftermarket through its control of actual scheduling and deliveries as will be discussed below.

Consumers of vehicles included virtually all institutions, from those servicing the Dictator directly (the central garage of Sovnarkhom), to ministries, to single enterprises and, in rare cases, individuals. Consumers directed their orders to all of the above-mentioned bodies, but most Consumers placed orders with their superiors hoping to become a part of the superior's request. The successful applicant had to pay for the vehicle out of its own investment budget - a technicality that could not stop superiors from "intercepting" vehicles for own use or redirecting them to others. Consumers could lose authorization to buy vehicles if they lacked funds. ${ }^{26}$ However, it was not the lack of funds that was usually binding but the limited supply of vehicles. In 1933, a major public transportation company (SoiuzTrans) was able to spend only half of its vehicle budget, even though the budget had been calculated on the erroneous assumption of falling vehicle prices. A large number of Consumers were disenfranchised by administrative measures and had to seek vehicles outside the formal system. A few disenfranchised themselves through "moral restraint." ${ }^{, 27}$ Private demand for vehicles was limited

\footnotetext{
${ }^{26}$ For example, a civil aviation supply organization was authorized to buy several vehicles in the first quarter of 1933. It was unable to pay on time, because of financial sanctions imposed by an arbitration court in March. Sanctions were lifted within two weeks, but the new quarter had begun, and the authorization was no longer valid. Although aviation had one of the highest priorities during this period, its order was placed back in line and fulfilled only a half year later. (GARF 5446.2029d.410).

${ }^{27}$ In the earlier years, when most vehicles were imported, some consumers refrained from making requests. As domestic production started growing, such hesitation evaporated: "Earlier we did not insist. Now with Gorky works in operation, I demand that you supply us." (Karaganda Oblast Administration, Kazakhstan, to Sovnarkom. GARF 5446.14.2029v.219-220).
} 
to about one percent. Organizations of lesser importance "unbound" to wholesale consumers or who lacked "connections" stood little chance of registering their demand.

Consumers clearly understood that the number of vehicles demanded far exceeded those available for distribution. This inherent "shortage" led Consumers to resort to the type of nonprice signaling hypothesized by Powell to increase the probability of getting vehicles. ${ }^{28}$ The Consumers' messaging "menu" was comprised of complaints and threats of plan failure. In a typical communication, representatives of the Bashkir Republic complained that their 1932 gold mining plan for 1932 called for 140 trucks but only 12 had been actually allocated by November, 1932. Their modest request for 40 trucks to prevent disruption of the plan was eventually rejected. ${ }^{29}$ Consumers also tried to assert their high priority by documenting their "real needs," but their calculations were often ignored by the overworked administrator (Gorbachev). A complementary Consumer strategy was to appeal to the Dictator's alleged preference for equity by claiming they had too few vehicles, sometimes understating their stocks. Small requests stood a better chance (Molotov to a Consumer: "Good, we approve. But don't ask for many..."30), but a modest request, if fulfilled, meant that the Consumer could not blame plan failure on the lack of vehicles, and transportation problems were among the most popular excuses for plan failure. Thus Consumers faced a tradeoff between quantity and certainty, insofar as smaller than optimal requests were likely to be fulfilled, while large requests risked full rejection.

The vehicle archives reveal the surprising fact that the Dictator and the Planner were never

\footnotetext{
${ }^{28}$ Powell, "Plan Execution and the Workability of Soviet Planning"

${ }^{29}$ GARF 5446.14.2029.46; GARF 5446.14a.628.132.

${ }^{30}$ GARF 5446.2029v.167.
} 
clear which organizations actually received vehicles because distribution plans were highly aggregated and monitoring was sporadic. Neither could the Planner check the credibility of threats of plan failure or determine whether consumers were asking for the "correct" number of trucks. The Dictator, in an attempt to ensure its decision-making prerogative, restricted the circle of those involved in allocation, and consequently limited its own capacity to collect and process information. Confronted with the Consumers' confusing signals, decision-makers (including Molotov himself) would periodically make site visits to gather direct information, for which they were later obliged to "pay" through the formation of patron-client relationships. The next vehicle order would read: "When you were with us you promised..." Once connected, Consumers produced new orders which had better chances of success, volunteered more information, including denunciations of others. ${ }^{31}$ The Dictator's attempts to make up for information deficits with such expeditions could hardly have improved economic efficiency; instead they caused closed clientele networks to form, where economic assets were exchanged for loyalty.

The aim of Soviet material balance planning was to balance demands with available supplies. The information distortions described above reveal that balanced plans could have been achieved only by chance. Early Soviet planning doctrine envisaged "certain miscalculations" that would require "corrections." 32 However, the very notion of "planning error" is hard to define when shortage makes plans inherently unbalanced, and the Dictator's

\footnotetext{
31 The director of a public library in Leningrad in 'exchange' for receiving a car shared his new knowledge of the black market for gasoline with his patron in the government, the Peoples Commissar of Inspection, and Politburo member Ian Rudzutak. (GARF 5446.14.2029d.391-392).

${ }^{32}$ Strumilin, Na Planovom Fronte 1920-1930gg.
} 
unlimited power prevents commitment to plans. These conditions made regular direct intervention of high government and party officials inevitable. In 1933 alone, Sovnarkom adopted 23 ad hoc decrees, allocating from one to one hundred vehicles, each outside of the regular quarterly planning process. The Politburo's own ad hoc interventions, which were either "legalized" as Sovnarkom decrees or inserted into quarterly plans as special instructions, could be extremely significant: In February of 1933, the Politburo allocated 525 cars (of the planned output of 550 cars!) to a single Consumer, the Commission for Harvest Monitoring, overriding the whole quarterly automobile plan. ${ }^{33}$ Another last-minute Politburo directive (which entered the first-quarter 1933 plan as a small footnote) redistributed 300 trucks, or about 30 percent of trucks allocated to the republics, to the construction materials industry. ${ }^{34}$

By the late 1930s decree-based interventions had become institutionalized; about one quarter of all vehicle allocations were made via ad hoc decrees in 1940. Breaches of the plan of this magnitude could not be repaired in the course of a single quarter. Claims of Consumers who had fallen prey to ad hoc reallocation were appended to the next quarter's plan as special sections entitled "coverage of previous quarter's non-deliveries." 35 Although the disruptive effects of large interventions were frustrating to the Planner, the Dictator regarded them as a strength - the system's ability to "mobilize" significant resource on short notice.

"Mobilizations," or transfers of existing stocks of vehicles from organization to organization, were used by all levels of political authorities to change the distribution of the stock to suit "immediate urgent needs". For example, after the 1933 decision to introduce

\footnotetext{
${ }^{33}$ RGASPI.17.3.915.

${ }^{34}$ GARF 5446.14a.628.139.

${ }^{35}$ GARF 5446.24a.3704.89.
} 
internal passports, dozens of Moscow organizations were obliged to share their cars with the militia to help "passportize" the population. In some cases, ad hoc decrees were accompanied by specific transfer orders. Large mobilizations required benediction in the form of Politburo decrees and evoked bitter complaints from organizations losing vehicles. In the case mentioned above, owners denounced the militia for non-designated use of cars. ${ }^{36}$ Transfers were typically justified by emergencies and were supposed to be temporary, although they proved difficult to reverse - a Soviet version of an old legal wisdom: "Possession is 90 percent of the law." An additional burden of mobilization on the permanent owner was the obligation to provide drivers, who remained on the owner's payroll.

The State and Party Archives do not allow us to compile data on aggregate transfers of existing vehicles. Mobilizations for harvesting alone involved thousands of trucks. Significant numbers of cars were also mobilized for police actions. Mobilizations were used to supply rapidly expanding organizations such as the labor camps administration, Gulag. In 1936, less than 20 percent of Gulag's vehicle acquisitions came through quarterly supply plans. The remaining 80 percent were "accepted free of charge" from other organizations within or outside its parent Ministry of Interior. ${ }^{37}$

\section{QUARTERLY PLANS: BALANCES AND SHOCKS}

The extraordinary value of the Soviet State and Party Archives is that they provide sequential drafts of operational quarterly plans for vehicle distributions prepared by different organizations. The sequence of drafts shows how the various actors responded to changes,

\footnotetext{
${ }^{36}$ GARF 5446.14.2030; GARF 5446.14.2029b.459-60.

${ }^{37}$ GARF 9414.3086.8.
} 
especially when output targets failed. We interpret Gosplan's draft plans, prepared for the Molotov Commission, as the expression of the Planner's plan. Plans approved by the Molotov Commission represent the Dictator's plans.

Table 1 provides five distribution plans that include extremely rare information on vehicle orders by wholesale Consumers (demand) and their satisfaction as intended by the Planner (planned amounts), and as finally approved by Dictator (actual allocations). Two of these plans fall in periods of adverse supply shocks (1932 and late 1937); the remaining three fall in periods of "normal" production. ${ }^{38}$ The "satisfaction rate" - the ratio of allocated to requested vehicles provides a rough measure of "shortage" in each period. Actual satisfaction rates rose from 15 percent in 1932 to a remarkable 88 percent in early 1937 before falling back to 47 percent during the supply shock of the fourth quarter of 1937. Thus, the early Soviet system began with an enormous "excess demand" for vehicles but was able to satisfy a remarkable nine out of ten consumers by early 1937.

Table 1 reveals differential patterns of adjustment on the part of the Planner and the Dictator. During the 1932 supply shock, Gosplan's ex ante distribution plan already cut requests by a whopping two-thirds to yield a projected success rate of 31.4 percent. Gosplan's cuts were fairly evenly distributed (coefficient of variation in satisfaction rates equals 26.4 percent), and Gosplan made few changes in rank orderings (Spearman rank correlation between requested and allocated vehicles is 0.976 ). The second column shows that the Dictator, faced

\footnotetext{
${ }^{38}$ In 1932, two unanticipated supply shocks caused significant delivery shortfalls: the newly constructed factory in Gorky (GAZ) did not come on line as planned, and the drop in agricultural export earnings forced a sharp reduction in vehicle imports. Supply shocks hit again vehicle allocations in the second half of 1937, possibly as a result of repression against the managers of GAZ.
} 
with an output less half that expected, chose to preserve the allocations of few "preferred customers," while fulfilling only 1 to 2 percent of the orders of lower priority organizations. The imposition of the Dictator's "sticky preferences" led to an extremely uneven (coefficient of variation reached 83.5 percent) and disproportionate (correlation with requests falls to about 0.5) distribution. The Dictator's reaction to the relatively small supply shock of the fourth quarter of 1937 - a 22 percent drop relative to the second quarter - fits the same pattern of adaptation (we lack Gosplan's plans for purposes of comparison). During the "normal" periods of the $3^{\text {rd }}$ and $4^{\text {th }}$ quarters of 1934 , the Dictator had no incentive to change the Planner's proposal significantly; hence, there was little difference in satisfaction rates and their variation. ${ }^{39}$ In the "normal" second quarter of 1937, when vehicle production reached four times the 1934 rate, there was an extraordinarily high correlation between requests and the final plan, and the Dictator also supported an almost uniform satisfaction rate.

\footnotetext{
${ }^{39}$ Note that the drop in correlation between the $3^{\text {rd }}$ and $4^{\text {th }}$ quarters of 1934 was due to organizational changes. Starting with the $4^{\text {th }}$ quarter, a growing share of trucks for agriculture was distributed not through the Ministry of Agriculture but through sales to collective farms. Also the Ministry of Supply was split into two agencies.
} 
Table 1: Vehicle Allocation During Supply Shocks (1932 and $4^{\text {th }}$ quarter 1937) and Periods of "Normalcy" (3rd and $4^{\text {th }}$ quarters 1934, $2^{\text {nd }}$ quarter 1937): Summary Statistics.

\begin{tabular}{|c|c|c|c|c|c|c|c|c|}
\hline & \multicolumn{2}{|c|}{1932} & \multicolumn{2}{|c|}{1934} & \multicolumn{2}{|c|}{1934} & 1937 & 1937 \\
\hline & & & \multicolumn{2}{|c|}{ 3rd quarter } & \multicolumn{2}{|c|}{4 th quarter } & \multirow{2}{*}{$\begin{array}{c}\begin{array}{c}\text { 2nd } \\
\text { quarter }\end{array} \\
\text { Actual }\end{array}$} & \multirow{2}{*}{$\begin{array}{c}\begin{array}{c}4 \text { th } \\
\text { quarter }\end{array} \\
\text { Actual }\end{array}$} \\
\hline & Planned & Actual & Planned & Actual & Planned & Actual & & \\
\hline $\begin{array}{l}\text { Average satisfaction } \\
\text { rate, \% }\end{array}$ & 31.4 & 15.0 & 41.7 & 39.6 & 53.6 & 51.2 & 87.6 & 46.5 \\
\hline $\begin{array}{l}\text { Coefficient of } \\
\text { variation in } \\
\text { satisfaction rates, \% }\end{array}$ & 26.4 & 83.5 & 47.8 & 48.5 & 37.5 & 37.8 & 18.3 & 53.3 \\
\hline Pearson $\mathrm{R}^{2}$ correlation & 0.996 & 0.919 & 0.962 & 0.962 & 0.807 & 0.778 & 0.98 & 0.747 \\
\hline $\begin{array}{l}\text { Spearman rank } \\
\text { correlation }\end{array}$ & 0.976 & $(0.542)$ & 0.957 & 0.951 & 0.861 & 0.881 & 0.978 & 0.645 \\
\hline
\end{tabular}

Coefficients in the two bottom rows show the correlation between requests and planned allocation or actual allocation, as specified in the appropriate column heading. The coefficient in brackets have a 90\% confidence level, the rest have 95\%. Coefficients of correlation between planned and actual allocation, not shown in the table, are all above 0.97 (except for 1932).

Although Table 1 demonstrates a profound difference between the Dictator's and the Planner's reactions to negative supply shocks, this difference could be ascribed, at least in part, to the lag between the preparation of drafts by the Planner and the Dictator's final decision based upon a lower expectation of output. Only the first quarter of 1932 yields a 'clean natural experiment' in which the Planner's revised plan and the Dictator's final plan respond to the same supply shock (Table 2). 
Table 2. $1^{\text {st }}$ quarter 1932 plans, cars: The Planning Aftermarket

\begin{tabular}{|c|c|c|c|c|c|}
\hline & \multirow{2}{*}{$\begin{array}{c}\text { "Optimistic" } \\
\text { Plan }\end{array}$} & \multicolumn{2}{|c|}{ "Pessimistic" Plan } & \multirow{2}{*}{$\begin{array}{c}\text { Dictator: } \\
\text { Delivery Plan }\end{array}$} & \multirow{2}{*}{$\begin{array}{c}\text { Supplier: } \\
\text { Actual } \\
\text { Deliveries }\end{array}$} \\
\hline & & Planner & $\begin{array}{c}\text { Dictator } \\
\text { (Final Plan) }\end{array}$ & & \\
\hline Total & 500 & 212 & 212 & 301 & 242 \\
\hline Army & 170 & 41 & 48 & 48 & 48 \\
\hline Agriculture & 65 & 24 & 24 & 27 & 27 \\
\hline Reserve & 50 & 25 & 31 & 29 & 31 \\
\hline $\begin{array}{l}\text { Large-scale } \\
\text { industry }\end{array}$ & 45 & 20 & 32 & 50 & 50 \\
\hline Police & 35 & 13 & 20 & 21 & 21 \\
\hline Miscellaneous* & 28 & 7 & 10 & 20 & 8 \\
\hline Other Ministries & 22 & 18 & 14 & 14 & 14 \\
\hline Russian Republic & 20 & 6 & 5 & 8 & 5 \\
\hline Moscow & 15 & 14 & 9 & 22 & 9 \\
\hline Leningrad & 25 & 6 & 6 & 30 & 6 \\
\hline Ukraine & 10 & 7 & 4 & 2 & 8 \\
\hline CART & 10 & 11 & 9 & 13 & 13 \\
\hline Other Republics & 5 & 20 & 0 & 17 & 2 \\
\hline Average & 38 & 16 & 16 & 23 & 19 \\
\hline Variation, $\%$ & 112 & 61.4 & 85.7 & 60.5 & 85.9 \\
\hline
\end{tabular}

* Various governmental organizations

Table 2 starts with Gosplan's first “optimistic" draft plan (expected production of 500 cars) compiled before the beginning of the quarter. Its "pessimistic" second draft (column 2) came two weeks into the quarter. A copy of the Planner's second draft contains penciled remarks that almost coincide with the Dictator's final plan. Thus, the Dictator's version of the "pessimistic plan" (column 3) directly overrides Planner's proposal (column 2) and demonstrates the Dictator's differential approach. As in Table 1, the Dictator prefers milder cuts than Gosplan for the highest ranking central ministers at the expense of less important Consumers. The fourth column reflects the recovery of production expectations that resulted in the Dictator's intervention some time in the middle of the quarter. ${ }^{40}$ Although this distribution is more even than the preceding one, more than half of the unanticipated increase in production 
was captured by three consumers, the large-scale industry ministry, ${ }^{41}$ Moscow, and Leningrad, who must have known to attend the session of the Molotov Commission. ${ }^{42}$

Why did the Planner opt for more equality and less reshuffling than the Dictator? Soviet planning doctrine assumed an iterative approximation to an "optimal" plan through interchange of information routed top-down (Gosplan's directives to ministries and further down to enterprises) and bottom-up (submission of draft plans by the agents in response). The Planner particularly feared that too large an initial supply/demand gap would result in too slow convergence. Secondly, Gosplan could have pursued an equity strategy of relatively uniform cuts on the assumption that enterprises had equal opportunities to "mobilize hidden reserves", or, in case of brutal necessity, obtain plan corrections from the Dictator. However, Gosplan's institutional interest was probably more important. Significant imbalances placed Gosplan in the middle of serious conflicts as unsatisfied customers barraged the Dictator with complaints. During the Great Terror of 1936-1938, Gosplan was accused of "wrecking" the quarterly distribution of gasoline but was never accused of "wrecking" the five-year plan. The Dictator, on the other hand, lacked an interest in equality, and viewed administrative "resource mobility" as a prime advantage allowing rapid adjustment of distributional policy. Clearly, the Dictator's preferences dominated because of its power to render ad hoc decrees and to order resource mobilizations.

The fact that almost 90 percent of requests were satisfied in the second quarter of 1937 (Table 1) is a remarkable statistic. Vehicle production grew from four thousand per quarter in

\footnotetext{
${ }^{40}$ The last column is discussed later, in a subsection entitled "Planning aftermarket."

${ }^{41}$ Large-scale industry refers to enterprises of the Supreme Council of the National Economy (VSNKh).

${ }^{42}$ GARF 5446.14.20295.25
} 
early 1932 to 40,000 per quarter in mid-1937. Production increases, while of undisputed importance, do not alone explain these high satisfaction rates. Vehicles were among the most prized of commodities; investment budgets typically included ample funds; and production increases had been widely publicized. Given the virtually unlimited nominal demand, these factors could have led to inflation of requests in excess of production growth rate. Therefore, we must look beyond increased production to explain the high satisfaction rate.

Table 3: Plan Comparisons: Planner's, Producer's, and Final Outcome.

Correlation of draft plans and final distribution.

\begin{tabular}{|c|c|c|c|c|}
\hline & 1933 & \multicolumn{3}{|c|}{1934} \\
\cline { 2 - 5 } & 3 quarter & 1 quarter & 2 quarter & 3 quarter \\
\hline Producer's plan & 0.994 & 0.965 & 0.942 & 0.956 \\
Planner's plan & 0.921 & 0.993 & 0.972 & 0.997 \\
\hline
\end{tabular}

Source: GARF. Quarterly plans; vehicle distributions by major users.

All correlation coefficients, except for the $2^{\text {nd }}$ quarter of 1934, are pairwise different at $95 \%$ confidence level.

Table 3 shows the correspondence between four quarterly plans ( $3^{\text {rd }}$ quarter of 1933 to the $3^{\text {rd }}$ quarter of 1934 - all from "normal" period ) drawn up by the Supplier, the Planner, and by the Dictator. Each had a different agenda. However, correlation coefficients for both sets of plans (relative to the Dictator) are typically above 95 percent, signifying that a basic distributional consensus was reached by late 1933; disagreement was only at the margin. Once this basic allocation had been set, it made no sense to make "outrageous" claims for vehicles, such as Gosplan felt was being done in early 1933. The tendency to make only marginal changes in plans is termed "planning from the achieved level." Table 1 and 3 together show that, during "good" years, when the economy settled near a stationary state, planning was done from the achieved level, while during supply shocks, planning from the achieved level had to be replaced 
by brutal Politburo interventions. This conclusion suggests an institutional role for the Dictator. A system devoid of a market adjustment mechanism cannot handle coordination without an intervening authority. A Planner relying exclusively on consumers' signaling would be without meaningful information in periods of increasing uncertainty. Therefore, the absence of a market makes the Soviet dictator, unlike a simple predatory ruler, an indispensable element of the economic system.

\section{UNOFFICIAL DISTRIBUTION}

Most stories of Soviet allocation planning would end with Tables 1 and 2 . They reveal the Dictator's participation in resource allocation beyond general target-setting and demonstrate complimentarily rather than identity of the institutional roles of the Dictator and the Planner. The formal picture of the Soviet economy as a centrally planned economy, where top-down command flow is decisive, is unchanged. The Soviet state and Party Archives, however, allow us to look below the formal level at informal activities Earlier studies of Soviet managers revealed a vast area of informal discretion at the enterprise level, including some trade in rationed commodities. ${ }^{43}$ The relatively simple Soviet economic hierarchy of the 1930s, comprised of less than a dozen economic ministries and headed by a few top political leaders, would seem to rule out informal allocation of a tightly-controlled investment good such as vehicles. The distribution of vehicles provides a window on the boundaries of quasi-markets for highly centralized products. Although most "unplanned" allocations of vehicles would be deliberately hidden from public view, the state and party archives provide an opportunity to study high-level unplanned allocation using information from inspections, investigations,

\footnotetext{
${ }^{43}$ Granick, Management of Industrial Firms in the USSR; Berliner, Factory and Manager in the USSR.
} 
complaints, and pure serendipity.

\section{Planning Aftermarket}

The "final" plan was approved at a high level of aggregation by branch and by region and was turned over to the Supplier to prepare the actual delivery plans for concrete customers. The Supplier, as the sole producer of vehicles, was in charge of the actual scheduling of deliveries and could refuse to deliver if none were available. The Supplier's exclusive information on vehicles available for delivery and the ephemeral character of rationing certificates (valid only for the quarter of issue), gave it a number of devices to influence the final outcome. First, the Supplier could influence its own allotment by claiming above-plan output. ${ }^{44}$ Second, the Supplier could allocate vehicles unclaimed by designated customers, such as those with rationing certificates but unable to pay on time. ${ }^{45}$ Third, the Supplier could be temporarily without delivery instructions due to the uneven scheduling of the Dictator's decisions. Even with their high "deficiency," the number of vehicles ready to ship at times exceeded the number of authorizations. ${ }^{46}$ The Supplier's control over the order of deliveries gave it partial control except when higher authorities scheduled deliveries themselves by a note from Molotov's secretary or an official decree.

${ }^{44}$ For example, Sovnarkom decree allowing the Ministry of Heavy Industry to "take 20 cars from Gorky Automobile Plant" (GAZ) if the production plan is overfulfilled by this amount. (Sovnarkom Resolution. May 27, 1933. GARF 5446.14a.628.21).

${ }^{45}$ GARF 5446.14.2029d.410.

46 The first quarter plan of 1933 was adopted only in mid February, and during those seven weeks the Supplier was issuing delivery authorizations on its own. On the last day of 1933, Gorky Auto Works reported that it had authorizations only for two-thirds of trucks and $88 \%$ of cars waiting for delivery and 
The last column of Table 2 provides a rare quantitative glimpse of the "planning aftermarket," namely, of the Supplier's latitude after the "final" plan was approved. Since the actual production of 242 cars was less than the targets of the final plan, the Supplier had to distribute the shortfall among Consumers. Its choice was to take care of itself (industry) and Consumers with strong connections to the Dictator (army, police, and CART), while cutting drastically less important Consumers, such as territorial authorities and miscellaneous Consumers. $^{47}$

The Supplier was less successful in getting more vehicles for itself through the formal planning process. As was noted above, the Supplier was allowed to prepare its own draft distribution plan for central authorities in late 1933 and early 1934. Unsurprisingly, the Supplier allotted itself the lion's share of vehicles. Starting in the $3^{\text {rd }}$ quarter of 1933, Supplier claimed $17.6 \%$ of vehicles for itself (the Ministry of Heavy Industry) and received $14.3 \% .^{48}$ By the $3^{\text {rd }}$ quarter of 1934 , the Supplier claimed $51.1 \%$ for itself but received only $12.2 \%$. Table 4 shows that, with the exception of the third quarter of 1933 (first column), the Dictator clearly favored the Planner's plans over those of the Supplier. ${ }^{49}$ As the Supplier's plans became more asked for instruction on how to proceed (GARF 5446.14.2029g.82).

${ }^{47}$ The Ministry of Heavy Industry (NKTP) records did not survive intact. Therefore, we have no microdata on the Supplier's discretionary allocation decisions. One reference in archival records makes it clear, though, that the Ministry did maintain its own reserve fund, which was used to serve both its own enterprises and outsiders such as a provincial newspaper (GARF 5446.14.2029d).

${ }^{48}$ The Supplier's claim was for its ministry, the Ministry of Heavy Industry.

${ }^{49}$ This exceptional plan was actually signed by Supplier's patron, the Minister of Heavy Industry and a member of the Politburo, Ordzhonikidze. Although Ordzhonikidze was increasingly advocating special interests of his ministry, he continued to represent national interests in this period (Khlevniuk, 
unbalanced in its own favor, the practice of producer planning was canceled. There was only one additional period, 1938, when the Supplier was allowed to draft a distribution plan. We have no data on this plan, but we assume that the results were the same, and the practice was canceled again.

Table 4: Comparison of Producer's Plan, Planner's Plan, and Dictator's Plan Mean absolute deviations of the two drafts from final outcome

\begin{tabular}{|c|c|c|c|c|}
\hline & 1933 & \multicolumn{3}{|c|}{1934} \\
\cline { 2 - 5 } & 3 quarter & 1 quarter & 2 quarter & 3 quarter \\
\hline Producer's plan & 0.269 & 0.546 & 0.712 & 0.615 \\
Planner's plan & 0.592 & 0.182 & 0.193 & 0.169 \\
\hline
\end{tabular}

All mean values are different at $99 \%$ confidence level.

The Supplier's de facto control rights over its output were narrowly limited, since the high concentration of vehicle production allowed the Dictator to monitor delivery with sufficient care to prevent highly arbitrary behavior. However, that Supplier had some distributive power, even for a commodity so valued by the Dictator, suggests that producers in less concentrated and less “important" branches of industry could exert significant influence over resource allocation.

\section{Redistribution}

Mobilizations and other forms of transfers by administrative order represented the only legal method of redistributing of existing stocks. Even when redistributions occurred through legal sale, permission from CART or even Molotov's Commission might still be needed. Mobilization would be required by such a system because only the government "owned" capital

Kvashonkin, Koshelova and Rogovaia, Stalinskoe Politburo v 30-e Gody). Thus, Supplier's plan for the third quarter of 1933 was a surrogate for the Dictator's own plan. 
assets and assigned control rights to put the assets to their best possible use. The current user's property rights "should have been transitory, depending on the whims of the true owner. Archival records, however, provide evidence that questions the official picture of strict state control of redistributions.

First, mobilization orders to transfer vehicles met fierce resistance, often successful. Even when legalized by special decrees, designated "donors" managed to disobey. For example, in January, 1933, Sovnarkom adopted a decree relocating 63 trucks from a large public transportation company (SoiuzTrans) to the Ministry of Water Transport. Six months later the recipient still had none of targeted trucks, which SoiuzTrans had hidden in various local organizations. ${ }^{50}$ Apparently, SoiuzTrans' benefit from protecting its vehicles from mobilization compensated it for disobeying a government decree from the highest level. A legal nuance should be noted: The transfer decree said nothing about the obligation of the donor to give only about the right of the recipient to take. Reallocations impinging the interests of high ranking organizations were difficult even to initiate, irrespective of the motivation. In late 1932, a report on an extensive investigation by the Dictator's own Worker and Peasant Inspection recommended that "incorrectly exploited" vehicles be placed into a single Moscow pool. Moscow organizations, including Gosplan, protested. Gosplan, a natural advocate of centralized management in theory, rejected the notion of a fleet monopoly when placed in the position of an organization "misusing" its vehicles. A small bureaucratic uprising, headed by Gosplan, was victorious and the Inspection's optimization initiative was buried.

Second, a large number of vehicle mobilizations were ordered by uncoordinated local state and party administrators. Despite the Planner's warnings against “anarchic” local mobilizations,

\footnotetext{
${ }^{50}$ GARF 5446.14.2029d.403.
} 
the Dictator neither prohibited local mobilizations nor regulated them, saying: "We consider it useless at this time." ${ }^{, 1}$ By refusing to intervene, the Dictator appeared weak to his agents, because chaotic local mobilizations had the side effect of ruining the defense ministry's mobilization plan of vehicles to be sequestered in case of emergency.

Third, many of the Dictator's mobilization decisions were initiated bottom-up, involving the Dictator as arbitrator in struggles among agent. In July 1933, an oil trust (Azneft of the Ministry of Heavy Industry) asked Molotov to give it 21 "Oil Export" (NefteExport of the Ministry of Foreign Trade) trucks held in customs in Baku for the "obvious" reason that the current owner no longer needed them for its defunct venture in Iran. The foreign trade ministry argued that it had bought the trucks with its own money earned in its operations in Iran, and was planning to relocate them to a new venture in Mongolia. The "arbiter" Molotov made a "fair" decision to give 10 of the trucks to Azneft, leaving 11 with the disgruntled trade ministry. The trade ministry continued to protest, but there is no evidence that Molotov's decision was reversed. ${ }^{52}$ A similar incident occurred in Odessa when the SoiuzTrans branch in Odessa was ordered to transfer temporarily nine buses to Intourist to serve a large group of foreign tourists. Both SoiuzTrans and Intourist claimed the buses after the tourists left. SoiuzTrans' claim was advocated by the Odessa First Party Secretary, who previously held an important position in the Party Central Committee's back office. The Intourist claim was lobbied by the figure-head President of the USSR, Kalinin. The decision signed by Molotov left seven buses with SoiuzTrans and two with Intourist, while giving seven new buses to Odessa from Ukraine's upcoming quota. Thus, the rivals get their satisfaction at the expense of a third party; Molotov's

\footnotetext{
${ }^{51}$ GARF 5446.14.2054.

${ }^{52}$ GARF 5446.14.2029g.132,140-3.
} 
decision overrode Ukraine's own quarterly distribution plan for buses. ${ }^{53}$

Finally, the archives reveal cases of organizations rejecting vehicles allocated by Dictator. In 1933, a trust of the Ministry of Foreign Trade was assigned 20 trucks to deliver supplies to remote areas near the Chinese border. The Minister of Trade refused, arguing that the trust was not up to the task and even offered to give up 40 trucks if another organization took over the task. The trade ministry finally accepted the trucks when threatened with prosecution for "sabotage." ${ }^{54}$ Apparently, this transfer initiated by the Dictator was a mixed blessing for the beneficiary since it assigned an obligation to produce more output.

Such anecdotal evidence of conflicts over redistributions shows that Consumers - the Dictator's agents - were pursuing their narrow interests. The Dictator had little information to judge which agent could use vehicles more efficiently. The Dictator had no reason to disregard any of the claims of its "loyal" agents, and disloyal agents were not supposed to occupy managerial positions. Under normal circumstances, the Dictator had no grounds to prefer one over the other. The unverifiable signals of the disputing parties, as in the Baku and Odessa cases, prompted qualified solutions such as "give some satisfaction to both sides." The lack of good signals may explain why the Dictator gave the right "to take" but not the obligation "to give", to split the disputed stock "fairly", its lack of commitment to enforce transfer decisions, or to stop unsanctioned local mobilizations. Such behavior placed the Dictator in a sort of "loyalty trap," awarding its agents with more effective control rights than intended.

\section{Interceptions}

Ministries and regional organizations and their representative offices in Moscow managed

\footnotetext{
${ }^{53}$ GARF 5446.14.2029g.109-13.

${ }^{54}$ GARF 5446.14.2033.
} 
the physical delivery of vehicles from the plants to regional distribution sites where they were to be picked up by buyers. This practice gave intermediary ministerial and regional authorities the opportunity either to "intercept" vehicles for their own use or to redirect them to other users. The archives reveal remarkably little checking of actual vehicle distributions. Only regional distributions to agricultural ministries were regularly monitored. In many cases, the Planner and the Dictator did not even know the disaggregated distribution, given the refusal of corporate customers to submit enterprise-level plans. ${ }^{55}$ To prevent interceptions of vehicles the Planner and the Dictator regulated part of the second-level distribution by special instructions. In 1933, special instructions prescribed final destinations for 8 percent of trucks below the ministry or regional level (by city, trust, or even by enterprise). Detailed distributions of cars, the most valuable commodity of all, were often made at the highest levels of government at least until 1938.

The archives provide ample anecdotal evidence that intercepted vehicles were used by the superior either for own use or for leasing. Investigations carried out, again by the Worker and Peasant Inspection in Moscow in late 1932 showed that at least 18 of 113 sampled organizations were using vehicles destined for to enterprises outside of Moscow "for purposes unrelated to their main duties," namely to earn cash. In some cases, such "misuse" resulted from mutual agreement between the intermediary and designated end user, especially when a relatively weak representative office was the interceptor of a vehicle intended for more powerful patrons. ${ }^{56}$ Interception and redirection introduce significant gaming elements into the formal planning

\footnotetext{
${ }^{55}$ Belova and Gregory, "Dictator, loyal, and opportunistic agents: The Soviet archives on creating the soviet economic system."

${ }^{56}$ GARF 5446.14a.628.70-75.
} 
process. Wholesale Consumers might forward orders that stood a better chance of fulfillment, knowing that they could be used in other ways during the actual distribution phase. The fact that vehicles could be sold or rented created market values in excess of the nominal price, which also would have influenced wholesale orders.

Disorder in the railroads added a stochastic element to secondary distribution. In one incident, an imported Buick allocated to a regional party committee in Siberia was routed by mistake to Alma-Ata in Central Asia, where a local party boss persuaded Molotov to let him keep the car. Molotov agreed but had to allocate another car to the original buyer. ${ }^{57}$ Such transport errors may have been deliberate. The Party Control Commission reported, for example, that Stalingrad railway dispatchers made "mistakes" in return for side payments by rerouting dozens of tractors to the Caucasus instead of to their original destinations in $1934{ }^{58}$

Interceptions and mobilizations show the extent of agents' effective control rights. The Dictator's ownership claims exceeded its monitoring capacity; de facto "ownership" rights had to be delegated downward, while reserving unlimited discretion above. The net result was a "nested dictatorship". Each agent behaved toward its subordinates as the Dictator behaved towards its subordinates. Local "dictators" were constrained in their actions primarily by the interests of other agents (SoiuzTrans vs. Intourist), while the Dictator was constrained only by the claims made by other governments, while the Dictator faced opportunistic behavior from ministries and regional authorities, ministries and regional authorities faced opportunistic behavior by enterprises and local authorities.

\footnotetext{
${ }^{57}$ GARF 5446.14.2029b.350.

${ }^{58}$ RGANI 6.1.5.52.
} 


\section{RETAIL MARKETS}

With the exception of reserve fund allotments, which went directly to end users, Soviet vehicle allocation was nominally a "wholesale" system, with planned allocations to large wholesale who were supposed to distribute to end users according to plan. Direct sales to individuals were limited to one percent, reserved primarily for luminaries and dignitaries. Berliner's and Granick's studies of Soviet management revealed an active inter-enterprise market in producer goods and raw materials; therefore, it would come as no great surprise to find an active retail market in vehicles, despite their strictly controlled nature. We already noted above an active rental market operated by wholesale consumers, largely in the Moscow area. Three retail markets for vehicles were tolerated and even promoted in the 1930s.

\section{Currency, Futures, and Reserve Funds}

Torgsin, originally a specialized trade network for servicing foreigners, was opened to Soviet citizens and organizations in 1931 and raised one third of all currency for Soviet imports in 1933-34. ${ }^{59}$ Torgsin sold a variety of goods, including vehicles, for gold, foreign currency, and antiques to Soviet citizens and resident aliens. In the early 1930s, Torgsin sold between one hundred and two hundred domestic cars and an unknown number of imported cars per year. ${ }^{60}$

\footnotetext{
${ }^{59}$ Osokina, Za Fasadom Stalinskogo Izobiliia.

${ }^{60}$ Torgsin operations, like other operations connected to hard currency and precious metals, were highly classified and were seldom mentioned in archival documents. Torgsin received allotments of vehicles through its superior, the Ministry of Foreign Trade. Only three times (in 1935) Torgsin appears in quarterly plans as a separate entry. Torgsin's share in the Ministry of Foreign Trade allotment was about $20 \%$ - about one hundred vehicles per year. The Ministry's allotment was reduced by approximately one half when Torgsin was closed. In 1933 Torgsin received at least 76 more cars and trucks from the Sovnarkom reserve. These numbers suggest that Torgsin received about 200 new vehicles per year.
} 
Abuse of vehicle sales by Torgsin was sufficient to spark independent investigations, which uncovered sales of vehicles at low prices for domestic currency to politically connected persons, such as the secret police (OGPU), and even to shady speculators. ${ }^{61}$ Even tightly-controlled Torgsin, which was almost a direct representative of the Dictator, opportunistically abused the intent to raise currency for state needs.

With the closing of Torgsin in 1936, another form of commercial vehicle trade was instituted; namely, the retail sales of trucks to collective farms to encourage "successful" collective farms that had accumulated sufficient funding and had fulfilled their procurement plans. Prior to 1936, trucks for agriculture had been allocated through appropriate ministries, mostly the Ministry of Agriculture.

61 The Moscow Party Control Commission investigation of Torgsin's distribution of 20 Ford cars revealed that eight were sold on the directive of the Minister of Foreign Trade to the Army and OGPU (secret police) at the nominal Soviet price; three were bought by Azerbaijan OGPU and one by Georgian Administration for Resort Construction whose officials appeared to be OGPU servicemen. These 12 vehicles were paid with "currency of various countries and gold scrap including tooth crowns" (probably a by-product of OGPU interrogations). Another 2 were bought by the East Siberian border guard administration, using a Moscow Wool Trust as a legal cover in return for one car. When the Wool Trust kept both cars, it was denounced by cheated border guards, and its director went to jail. Another wool trust bought one car in exchange for a Soviet-built truck; two cars were bought by a housing co-operative of foreign professionals and exchanged for trucks from Aeroflot. The final two cars were bought by a Soviet engineer who negotiated to pay only half of the price in hard currency and by a fictitious foreigner, "Arthur Smith," who was later identified as the swindler Kogan, previously an Intourist employee. (GARF 5446.14ł.628.76-81). 
"Auto-obligations" (avtoobiazatelstva) represented the numerically most significant type of "retail" sales. "Auto-obligations" were "futures" for the products of auto works, which the government sold in period 1929 to 1932 in the expectation of a near-term rise of domestic auto production. When production lagged behind expectations in 1932, there were insufficient vehicles to back these futures, and auto-obligations became a sort of lottery ticket. In 1933, some 1500 such obligations came due, almost one third of which were held by individuals. Even significant holders of obligations, like the Kiev Party Committee, were initially rejected. The "right" to buy a car, nominally guaranteed by government, was at the bottom of the Dictator's priority list, although the government's “defaults" weakened its reputation. ${ }^{62}$ Despite Gosplan's proposal to pay all obligations by the first half of 1934, vehicles allotted for the holders of past

${ }^{62}$ In April of 1933 deputy head of Gosplan, Mezhlauk, addressed to Sovnarkom a letter urging it to satisfy the holders of auto obligations. In his view, "this would increase the trust not only to those already issued obligations but also of other obligations being issued by our industry, which are equally important as state loans." An enclosed memo presented current statistics: by April 21, 1933, 626 truck and 872 car obligations, already past due or due in 1933, had been submitted. 351 car obligations were held by individuals, 280 by Avtodor, and the rest by production cooperatives and public organizations. The majority of truck obligations belonged to production cooperatives. About two thirds of all obligations pending were issued in 1931. (GARF 4372.31.36.228-231). Avtodor was legally a public organization, whose primary goals were training of drivers and 'propaganda of automobile transport', i.e. basically fund-raising for local road construction through lotteries. However, several petitions found in Sovnarkom files suggest that members joined Avtodor for the opportunity to buy a car, suggesting that Avtodor was reselling stocks obtained through auto obligations. 
due obligation covered less than $20 \% .^{63}$ Most of auto obligations were ultimately paid back in 1935 after significant improvement in production. In 1935, 930 vehicles or about $1 \%$ of total output went to auto obligations holders.

A relatively small but significant number of vehicles were allocated directly to "retail" customers by the Molotov Commission from Sovnarkom's "reserve fund." This reserve fund comprised 1 to 10 percent of planned production in the 1930s, a figure that gradually declined with the growing importance of ad hoc distributions. Unlike other planned quotas, the Molotov Commission itself was not constrained by fixed quotas. Commissioners usually allocated more vehicles from the reserve than it contained, but on occasion they gave less even though the queue of requests was never empty. Allocations from the reserve fund allow us to see Dictator's own preferences uninfluenced by intermediate planning bodies, such as Gosplan. We have prepared a separate analysis of the reserve fund, and we shall not dwell on this issue here. ${ }^{64}$ Our analysis shows that the reserve fund was used primarily for political rather than economic goals.

\section{Unofficial Secondary Markets}

The Dictator established strict rules to limit private sales of vehicles. Organizations could not sell vehicles at prices exceeding the original price minus depreciation; they could not sell to individuals before the vehicle's complete depreciation if it could be sold to an organization; and permission of the trade ministry was required to sell imported vehicles. Clearly the first prohibition was hardly acceptable to prospective sellers in view of the considerable inflation, the second was easily evaded, and the third was made obsolete by the disappearance of the ministry of trade. (We did not find the evidence that this instruction was subsequently revised). It is

\footnotetext{
${ }^{63}$ RGAE 4372.31.36.228-231.

${ }^{64}$ Lazarev and Gregory, "Dictators and Cars."
} 
noteworthy that CART, the representative of Consumers' interests, criticized these sales restrictions, arguing "there is no need to force organizations to keep useless vehicles." 65

Because vehicle sales in secondary markets were basically illegal, it is hard to find evidence of such activity. Nevertheless, on September 24, 1934, Stalin's First Deputy, Kaganovich wrote to Stalin that trucks were being purchased for grain (1.5-ton truck for 4000 puds of grain). ${ }^{66}$ Some notion of the scale of the secondary market can be derived from an investigation by the Central Party Control Commission: Stalingrad region had 2000 registered cars and trucks at the beginning of 1933. During the year, 500 were reported unrepairable and 220 were "lost." A large number of organizations, not officially allowed to own vehicles, had bought used cars and reassembled them, or purchased documents of decommissioned vehicles and assembled new ones from spare parts. Or they "simply stole" the cars, an expression that could have encompassed illegal purchasing. A capital stock census of the Central Statistical Bureau provides further information on secondary markets. According to the organization of small-scale establishments, Vsekopromsovest, its transport cooperatives acquired 87 vehicles in 1935, while according to quarterly plans all of Vsekpromsovet was allocated only 30 vehicles. ${ }^{67}$

Underground auto works, which assembled vehicles from spare parts were enough of a problem for the Dictator to prohibit them. No one was ever punished, as was admitted in the above-mentioned report on Stalingrad, because there was no away to distinguish between rebuilding an old car and assembling a new one from spare parts. The Dictator's opposition to home-vehicle production reflects its general aversion to unplanned resource exchange,

\footnotetext{
${ }^{65}$ GARF 5446.11.1760.

${ }^{66}$ We are grateful to R.W. Davies for this reference (RGASPI 558.11.742,11.99-104).

${ }^{67}$ RGAE 1562.11.106.16-22.
} 
especially one that reduces the supply of spare parts. Moreover, gray market transactions and unauthorized local mobilizations destroyed information on truck locations needed for defensemobilization planning. A final source of the Dictator's opposition was that valuable resources, such as vehicles, were supposed to be available only from the state, as a reward for outstanding work or for "success in the building of socialism." 68 Only a Comrade Stalin or Molotov should be able to give you a car, not a mechanic from local repair shop.

\section{CONCLUSIONS}

Scholars of the Soviet economy have emphasized the difference between planned and informal economic activity. Berliner's and Granick's classic studies of the Soviet enterprise revealed what was then regarded as a surprising degree of discretionary managerial authority, especially with respect to supply. ${ }^{69}$ The Soviet manager's protagonist (principal) was the industrial ministry, which handed down the government's tasks and allotted "funded" resources to the industrial manager "agent." Our study of vehicle allocation focuses on the highest-level interactions between the Dictator, as represented by the Molotov Commission, and "wholesale" users as represented by industrial ministries and regional governmental authorities. That these industrial ministers and regional leaders constituted the top leadership of the Soviet Union suggests that all parties should have shared a stake in the "national interest." In theory, vehicles should have been easy to centralize: relatively few; only three models; and distribution directly by the Dictator. These facts alone would appear to severely limit principal/agent problems with

\footnotetext{
${ }^{68}$ Gregory, Command: How Stalin Created the Soviet Administrative-Command Economy, shows that the ministries used vehicles to reward successful directors of large enterprises.

${ }^{69}$ Berliner, Factory and Manager in the USSR; Granick, Management of Industrial Firms in the USSR.
} 
respect to vehicle distribution.

The reality of vehicle distribution was quite different. The highest "corporate" users had widespread "unplanned" discretion, gained through superior local information and the center's unwillingness to interfere and challenge. Major industrial consumers used this discretion opportunistically to increase their share of output, to understate current stocks, to use vehicles that had been allotted to their subordinates, to sell vehicles to individuals, and even to disobey mobilization decrees. Gosplan, the Planner, never planned actual wholesale transactions, even for a highly centralized product like vehicles, avoiding what it perceived as dangerous "syndicate work." The supplier had "delivery margins" large enough to supply himself and others. The Dictator and its Planner could not monitor second-level distributions and did not even know current vehicle stocks. Major industrial leaders would not have engaged in such opportunistic behavior unless the perceived benefits outweighed the costs in terms of possible detection and punishment.

Necessary and sufficient conditions were in place for the existence of informal secondary markets despite the threat of repression: The presence of a large number of consumers, with cash and barter resources and excluded from the formal process, provided fertile soil for secondary markets, home assembly, fraud, and illegal rental operations. The Dictator's claims to "ownership" of all capital assets were disproportionate relative to its capability to monitor and enforce its claims. Therefore, the Dictator had to cede effective control rights and the rents that accrued therefrom to its agents.

The system's highest industrial and regional authorities treated their agents, the industrial enterprises and trusts, in the same way they were treated by their principal, the Molotov Commission. The economic system thus constituted a nested dictatorship, which tended to 
reproduce itself, even in terms of organizational structure at every hierarchical level. ${ }^{70}$ Industrial ministries, regional organizations, local party organizations, or any other agent entrusted by its superior with some resource-allocation power, engaged in arbitrary "resource maneuvering" through mobilizations, interceptions, and rule-breaking, copying the behavior of its superior, who could not prevent such activity due to inferior information and/or the need for loyalty.

Redistribution of centrally-planned capital goods, such as vehicles, either initiated from above or by a predatory rival, created a struggle for control rights. Vehicle users had to fight for new production and to keep existing stocks. The anecdotes of attempted hostile takeovers show that a Soviet "market" for corporate-asset control existed, a fact confirmed by other studies, ${ }^{71}$ which find hostile takeovers of whole industrial branches by rival ministries. Clearly, economies require a mechanism to redistribute long-lived capital goods; the Soviet system used mobilizations and takeovers to accomplish this end. Our case study of vehicles illustrates the basic property-rights logic of the system: The Dictator chose a highly centralized system to control valuable resources. Only the Dictator was to have property rights. Therefore, every allocation decision was revertible from the implementation of the quarterly plan to the postpurchase transfer of existing cars. Agents, in their struggle for de facto property rights, sought to obtain resources for their sole use, rather than rely upon the services of large centralized providers. Even Gosplan resisted the creation of a centralized Moscow motor pool. Petitioners

\footnotetext{
${ }^{70}$ Markevich and Gregory, "The Ministry of Heavy Industry: Soviet Resource Allocation in the Early Years."

${ }^{71}$ Markevich and Gregory, "The Ministry of Heavy Industry: Soviet Resource Allocation in the Early Years"; Belova and Gregory, "Dictator, loyal, and opportunistic agents: The Soviet archives on creating the soviet economic system.”
} 
justified their permanent need for an "own" car or truck and did not ask for temporary assignments of vehicles. Even faithful agents resisted transfer orders that the Dictator felt were in the larger interest, preferring certain control as giving them a better chance to fulfill the Dictator's plans.

The resulting system of conditional control rights, which was expected to provide the Dictator with comprehensive and transparent instruments for resource management, actually encouraged agents to conceal their actions. The more rigid the restrictions on non-sanctioned transactions, the more agents engaged in them. Thus, it was not only "fatal conceit", the HayekMises notion of impossibility of solving economy-wide problems from a single center, that created complex information problems. The mere existence of an administrative-command hierarchy, which was designed to implement solutions favorable to the Dictator, brought about the behavior of economic agents that was undermining the system of centralized control. 


\section{BIBLIOGRAPHY}

Belova, E. and Gregory, P., "Dictator, loyal, and opportunistic agents: The Soviet archives on creating the soviet economic system", Public Choice, forthcoming (2001).

Berliner, J., Factory and Manager in the USSR (Cambridge, Mass.: Harvard University Press, 1957).

Gosplan SSSR, Metodicheskie Ukazanii k Rasrabotke Gosudarstvennykh Planov Ekonomicheskogo i Sotsial'nogo Razvitiia SSSR (Moscow: Economic, 1980).

Granick, D., Management of Industrial Firms in the USSR (New York: Columbia University Press, 1954).

Gregory, P., "The Dictator's Orders," in Gregory, P., (ed.) Behind the Façade of Stalin's Command Economy (Palo Alto: Hoover Press, 2001)

Gregory, P., Restructuring the Soviet Economic Bureaucracy (New York: Cambridge University Press, 1990).

Gregory, P. and Stuart, R., Russian and Soviet Economic Structure and Performance, $6^{\text {th }}$ ed. (Reading, MA: Addison Wesley, 1998).

Gregory, P. and Markevich, A., "The Ministry of Heavy Industry: Soviet Resource Allocation in the Early Years", University of Houston Working Paper (2000).

Grossman, G., "The Second Economy of the USSR," Problems of Communism, 26 (September-October, 1977), pp. 25-40.

Hayek, F.A., "Socialist Calculation: The Competitive Solution", Economica, 7 (1940), pp. 125-149. 
Khlevniuk, O.V., Stalin i Ordzhonikidze: Koflikty v Politburo v 30-e Gody (Moscow: Izdatel'ski tsentr Rossiia molodaia, 1993).

Hunter, H., “Optimal Tautness in Development Planning”, Economic Development and Cultural Change, 9 (1961), pp. 561-72.

Hunter, H. and Szyrmer, J., Faulty Foundations: Soviet Economic Policies 1928-1940 (Princeton: Princeton University Press, 1992).

Jasny, Soviet Industrialization, 1928-1942 (Chicago: University of Chicago Press, 1961).

Kornai, J., Economics of Shortage (Amsterdam-New York-Oxford: North-Holland Publishing Company, 1980)

Kushnirsky, F., Soviet Economic Planning, 1965-80 (Boulder, Colorado: Westview, 1982).

Lazarev, V. and Gregory, P., "Dictators and Cars", The Hoover Institution Working Paper Series in International Studies, I-99-6, (1999).

Mises, L., Socialism: An Economic and Sociological Analysis, transl. J. Kahane (London: Jonathyn Cape Ltd., 1936).

Osokina, E., Za Fasadom Stalinskogo Izobiliia. (Moscow: Rosspen, 1997)

Powell, R., "Plan Execution and the Workability of Soviet Planning", J. Comparative Economics, 1 (1977), pp. 69-73.

Shleifer and Vishny, "Pervasive Shortages under Socialism."

Stalinskoe Politburo v 30-e Gody (ed. Khlevniuk, O.V., Kvashonkin, A.V., Koshelova, L.P., and Rogovaia L.A. ) (Moscow: AIRO-XX, 1995). 
State Archival Service of the Russian Federation, A research Guide: I. Guide to Collections (American editors: William Chase and Jeffrey Burds) (Moscow: Blagovest, 1994), referred to as GARF.

Treml, V., "Production and Consumption of Alcoholic Beverages in the USSR: A Statistical Study,” Journal of Studies on Alcohol, vol. 36 (March 1975).

Wilhelm, J., "The Soviet Union Has an Administered Not a Planned Economy," Soviet Studies, 37 (January 1985), pp. 118-30.

Zaleski, E., Stalinist Planning for Economic Growth 1933-1952 (Chapel Hill: University of North Caroline Press, 1980).

\section{ARCHIVAL SOURCES}

References to archival material are given in the following notation: Archive Fond.Register.File: Page.

GARF. State Archive of the Russian Federation (Gosudarstvenny arkhiv Rosiyskoy Federatsii): Fond 5446 - Council of Ministers of the USSR)

Fond 9414 - Main Administration of Labor Camps (GULAG).

RGAE. Russian State Archive of the Economy (Gosudarstvenny arkhiv ekonomiki):

Fond 1562 - Central Statistical Bureau (TsSU);

Fond 4372 - State Planning Commision (Gosplan);

Fond 7622 - Ministry of Heavy Industry (NKTP).

RGASPI. Former Central Party Archive: Fond 17, Opis 3 - Politburo.

RGANI. Former Archive of the Central Committee of the CPSU: Fond 6 - Central Party Control Commission. 